\title{
Archiwista na powstańczym Żoliborzu. Dziennik Piotra Bańkowskiego z perspektywy egodokumentalnej
}

D) owstanie warszawskie od kilku lat jest symbolem walki, patriotyzmu i męczeń-
stwa Polaków. Na początku sierpnia, każdego roku rozbrzmiewające hasła nie dają zapomnieć o toczonych walkach w stolicy. W 70 rocznicę wybuchu powstania Naczelna Dyrekcja Archiwów Państwowych postanowiła uczcić wydarzenia sprzed lat, wydając wspomnienia archiwisty - Piotra Bańkowskiego ${ }^{1}$. Publikacja ta stanowi źródło informacji o przeszłości, a także jest doskonałym przyczynkiem do prezentacji poglądów i osobowości autora wspomnień.

Dziennik wzbogacony został o biografię Bańkowskiego i wstęp autorstwa Anity Chodkowskiej. Ponadto na końcu zamieszczono sprawozdanie Bańkowskiego dla powojennych władz archiwalnych, które zawiera krótki opis prac wykonanych przez niego w Forcie Sokolnickiego, dodatkowo załączono wykaz publikacji naukowych, artykułów, recenzji i not sprawozdawczych archiwisty. Publikacja posiada kilkanaście fotografii miejsc i postaci przewijających się w tekście. Dla przybliżenia czytelnikowi osób, o których pisał archiwista, edytorka dziennika dodaje informacje w przypisach.

Zawierucha powstańcza sprawiła, że oryginalne zapiski rozproszone były w różnych miejscach Warszawy, a ich stan fizyczny utrudniał odczytanie. Bańkowski zdecydował się więc na ponowne przepisanie dziennika w Kielcach, w 1945 r. Nowy tekst jest niepełny (nie miał w posiadaniu wszystkich notatek) i opatrzony został autokorektą. Wydawczyni zdecydowała się na opublikowanie pierwopisu, uzupełniając jedynie luki w tekście późniejszą wersją. Jak sama podkreśla w pierwotnych zapiskach odnaleźć można większe pokłady emocji, następna uchodzi już za bardziej wygładzoną i literacką. Ta informacja o różnicach w dziennikach jest przydatna chociażby dla badających tekst w kontekście egodokumentalności.

${ }^{1}$ P. Bańkowski, Archiwista na powstańczym Żoliborzu. Wspomnienia sierpień - wrzesień 1944, oprac. A. Chodkowska, Warszawa 2014, ss. 194. 
Wspomnienia zaczynają się 4 VIII, w pierwszych dniach powstania, a kończą $1 \mathrm{X}$ 1944 r., kiedy to warszawianie zostają przewiezieni w otwartych wagonach z Pruszkowa do Jędrzejowa, podczas nocnej ulewy, z myślą, że to już koniec. Pamiętnik opatrzony został dodatkowym wpisem z 25 III 1945 r., w którym Bańkowski opisuje dzień kapitulacji fortu.

Dziennik to kompilacja obserwatora zbrojnego zrywu, archiwisty i zwykłego człowieka borykającego się z bolączkami dnia codziennego. W swoich zapiskach starał się być skrupulatny i rzeczowy. Rzadko pozwalał sobie na uwagi dotyczące stricte życia prywatnego. Wspomnienia miały posłużyć jako źródło wiedzy o tamtych dniach oraz losów archiwaliów, nad którymi sprawował pieczę, a nie studium osobistych przeżyć. Publikacja przedstawia powstanie z punktu widzenia intelektualisty czytającego Tragedię kobiety Stefana Zweiga i porządkującego korespondencję Wincentego Lutosławskiego, człowieka walczącego o zabezpieczenie pojedynczego dokumentu o wartości historycznej. Myślącego kategoriami archiwalnymi, o gromadzeniu i zachowaniu chociażby ulotek z odezwami niemieckich generałów, który do walk toczących się w Warszawie podchodzi bez większych emocji, nie myśląc o włączeniu się do boju.

Do Bańkowskiego docierały informacje o planowanym powstaniu, on jednak bezpośrednio nie brał w nim udziału. Krótko przed wybuchem walk pracował w Archiwum Akt Nowych przy ul. Rakowieckiej, ale czasami zaglądał do Archiwum Skarbowego na Podwalu. Tam też spędził pierwsze dni powstania, usiłując przedostać się do swojego domu na Żoliborzu.

Początek walk starał się opisać jak najdokładniej. Choć były to burzliwe dni, nie zabrakło rozsądnej życzliwości ze strony kolegów i znajomych. Bańkowski chciał jak najszybciej przedostać się do swojego mieszkania, kamienicy Feniks, w którym czekała schorowana żona. Opisywał uliczne zamieszki, bezsenne noce w piwnicach, schronach i u przyjaciół, przytaczał opowiadania walczących, próbował zabezpieczyć dorobek swojego życia.

Kiedy dalsze bytowanie w mieszkaniu stało się niemożliwe, wraz z żoną przeniósł się na ul. Dygasińskiego, do Pani Dehnel, a pod koniec powstania do Fortu Sokolnickiego, gdzie został do końca walk.

Z analizy tekstu wynika, że autor przywiązywał wagę do formy wypowiedzi. Cały dziennik utrzymany jest na wysokim poziomie stylistycznym i literackim (np. „Czy ten względny spokój, jaki mamy znów dziś od wczesnego rana, nie stwarza złudzeń, poza którymi kryje się wciąż fatalne, nieprzeniknione jutro? Czy ta rzeczywistość ponura niechybnie nie czai się gdzieś za naszymi plecami?! A ludzie coraz spokojniej chodzą po ulicach Żoliborza, jakby to, co się dzieje w Warszawie, nie mogło zwalić się lada chwila na nas...") ${ }^{2}$.

2 Tamże, s. 46. 
Autor starał się odwzorować jak najwiarygodniej obraz zmieniającej się Warszawy. Dzięki jego opisom nie tylko dowiadujemy się o stawianych barykadach, bombardowaniach, czy zniszczonych budynkach. Poczuć można też zapach ludzkiego strachu, chorób, usłyszeć szepty pacierzy. Z jego słów wyłania się także zwykłe życie, zrywających warzywa z ogródka i próbujących zrobić zakupy na prowizorycznym targowisku za niebagatelne kwoty („Korzystając z 2 godzin ciszy, od 6 do 8 marymonciarze nanieśli kartofli i buraków. Ale kartofle poszły w cenę - kilo kosztuje 70 zł. Staniały natomiast buraki, po $20 \mathrm{zł")})^{3}$ oraz pijących herbatę na towarzyskim spotkaniu.

W mieście bardzo zróżnicowanym społecznie, w którym żyły obok siebie różne warstwy i grupy, nagle zmuszono wszystkich do dzielenia jednego „łoża”. Autor jawnie wyrażał stosunek do tzw. barakowców, biedoty Żoliborza. „Gdy się słucha rozmów i wywodów tych »barakowców«, człowiek słupieje ze zdumienia, jakie warunki doprowadziły do wyrośnięcia ludzi, dla których nie istnieją żadne zasady religijne, moralne, prawne, polityczne, polskość, patriotyzm, najprymitywniejsze podstawy kultury - to pojęcia dla nich obce, a nawet wrogie"4. Uwag utrzymanych w takim tonie pod adresem „barakowców” nie brakuje. Świadczyć to może o antypatii autora do niższej klasy społecznej. W wielu miejscach tekstu, nieświadomie zdradza, że ceni ludzi wykształconych i takimi pragnie się otaczać. Dopiero, kiedy owi inteligenci go zawiodą, dostrzega szlachetność wśród ludzi prostych.

W dzienniku, jak wspomniałam, odszukujemy informacje o problemach z zaopatrzeniem, żywnością, dostępem do wody pitnej, brakiem miejsc noclegowych. Z relacji autora wynika, że był to złoty okres dla handlarzy żywnością. Osoby mające do tego smykałkę mogły naprawdę wzbogacić się na czasach walki.

Bańkowski starał się wykonywać obowiązki archiwisty systematycznie, tak jakby wojny nie było. Wśród materiałów odnalazł korespondencję Wincentego Lutosławskiego z rodziną, którą pragnął uporządkować. Pomimo natłoku spraw wracał do korespondencji, przeglądał pocztówki, zdarzało mu się również zamieszczać co bardziej interesujące fragmenty w dzienniku. Podczas powstania otrzymywał dodatkowe dokumenty do przechowywania, np. dzienniki zajęć, katalog klasy III i jak to nazwał „cenne papiery kancelaryjne” szkoły koedukacyjnej im. Bolesława Limanowskiego. Przez kilka tygodni prosił dyrektora Michała Mendysa o wyrobienie zaświadczenia potwierdzającego funkcję zastępcy dyrektora archiwum. Informacje o trudnościach w zdobyciu zaświadczenia były często pojawiającym się wątkiem w dzienniku.

Dużo miejsca w dzienniku zajmują opisy heroicznej walki o pomieszczenia i zabezpieczenie archiwaliów w forcie. „Wobec groźnej postawy tłumu, musiałem się zgodzić na otwarcie dla nich [mieszkańców Warszawy, pozbawionych domów] sali z żelazną kratą i z aktami Metryki Koronnej. Upadło [?], o ile było można, poleciłem zabezpie-

3 Tamże, s. 96.

4 Tamże, s. 89. 
czyć paczki, które obstawiono skrzyniami. Po otwarciu pierwsi rzucili się »barakowcy« [...] Mnóstwo osób nocuje po schodach, po przejściach, nie ma mowy o jakiś leżących miejscach w kazamatach. [tu pode mną, w kazamatach - królestwo ferajny - a ja czuję to, jestem wśród nich intruzem]"'.

Archiwista, pasjonat, wspominał o rozterkach moralnych. Tekst pełen jest emocji, autor był tak przejęty sytuacją, że zapominał używać kulturalnego stylu wypowiedzi. I chociaż pisał o poważnych sprawach, to momentami jego relację czyta się jak tragikomedię. Kto jest ważniejszy: człowiek czy dokument? Był zdruzgotany, kiedy jeden z tzw. delegatów wypowiedział się na temat jego pracy: „Ja sram na te papiery, nam nie te śmiecie potrzebne, a kuchnia, i jak nam nie dacie miejsca, to damy wam baty,

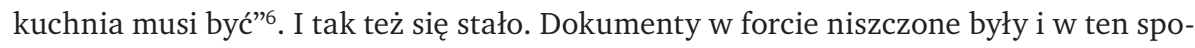
sób: „Po prostu szczali między akta [...] Szczanie w salach, gdzie pracuje personel techniczno-rzemieślniczy, jest zjawiskiem dość częstym, mimo że zwracałem uwage”". Nie potrafił zrozumieć braku poszanowania jego pracy ze strony innych osób: „To było najprzykrzejsze, że wśród tych inteligentów zabrakło ludzi światlejszych, którzy stanęli w obronie resztek przeszłości, może dziś już jedynych"7. Mają przed oczyma tylko szpital, chorych, z pełną gębą frazesów, że „trzeba ratować człowieka”. Wiadomości o niszczeniu dokumentów jest więcej, w szczególności w ostatnich dniach powstania: „właśnie dziś, gdy pada deszcz, a szereg ludzi w tę i przeciwną stronę przechodzi tymi drzwiami depcząc po księgach. Z ksiąg tych urządzono sobie posłania na noc i do tej

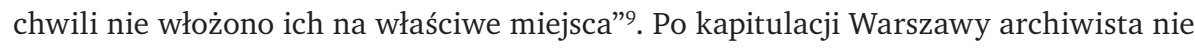
miał już wpływu na dokumenty tam zostawione. „Po opuszczeniu przez nas fortu, gospodarzami zostali tam Niemcy i w pewnym sensie - w ciągu października - szpital [...] Straty, jakie archiwa poniosły, miały miejsce prawie wyłącznie tylko na parterze, w niezabezpieczonych pokojach"10.

W dzienniku odnajdujemy kilka form literackich: sprawozdania z linii frontu, pamiętnika oraz powieści grozy. Wspomnienia z powstania to nie tylko przejmująca opowieść o ludziach uwięzionych w bombardowanym mieście, walce z wrogiem, chorobami i strachem, to przede wszystkim opowieść o losach polskich archiwaliów, bezsilności pracowników, ignorancji powstańców i mieszkańców. Czas wojny nie sprzyjał kulturze, ale dzięki determinacji osób zaangażowanych w ochronę dziedzictwa kulturowego, takich jak archiwista z Żoliborza, udało się zminimalizować nieuniknione straty. Dzięki tej pozycji uświadamiamy sobie, że nie tylko ludzie przeżywają dramaty, ale i rzeczy, które też w pewien sposób cierpią. Obiektem zachowań

\footnotetext{
5 Tamże, s. 117.

6 Tamże, s. 132.

7 Tamże, s. 133.

8 Tamże, s. 140.

9 Tamże, s. 144.

10 Tamże, s. 178.
} 
cywilów i archiwisty nie były te same rzeczy. Dla Bańkowskiego archiwalia to rzeczy święte, dla warszawian sterta makulatury, którą można wykorzystać jako posłania i do ochrony przed chłodem. Autora z dokumentami łączyła specyficzna relacja. Można sądzić, że materiały archiwalne w jakiś sposób ukształtowały Bańkowskiego i urealniły typowy dla niego sposób bycia.

Choć jest to dziennik, nie chcę oceniać realizmu opisu wydarzeń. To, w jaki sposób autor pisze o tym, co widział, co czuł, jakie decyzje podejmował, jest największym walorem autentycznych wspomnień. I nawet jeśli niektóre historie mogą wydawać się wyolbrzymione, inne zbagatelizowane, jest to jego opowieść i sposób wyrażania siebie. Bańkowski miał niezwykłe poczucie misji, jego zaangażowanie w prace archiwalne daje dowód na to, że świat wartości archiwisty jest dość osobliwy, momentami nie dość „humanitarny” z perspektywy odbioru społecznego. To bezpieczeństwo dokumentów, a nie wolna Warszawa wydają się ważniejsze dla Bańkowskiego. Opieka nad archiwami ułatwiła mu zaadoptowanie się w wojennej rzeczywistości i - co ważniejsze - pozwoliła na pozostanie sobą oraz utrzymanie statusu społecznego.

Dziennik napisany przez Bańkowskiego jest dobrym materiałem źródłowym do badań nad specyficzną mentalnością archiwistów, historią życia powstańców, sferą życia przedmiotów (archiwaliów), nierozerwalnym związku między archiwaliami a archiwistami.

Kamila Siuda

(Uniwersytet Mikołaja Kopernika w Toruniu) kamila.s@doktorant.umk.pl 
